\title{
Increased sensitivity of African American triple negative breast cancer cells to nitric oxide-induced mitochondria-mediated apoptosis
}

Luis Martinez ${ }^{1}$, Easter Thames ${ }^{2}$, Jinna Kim ${ }^{3}$, Gautam Chaudhuri ${ }^{4,5}$, Rajan Singh ${ }^{3,4,5}$ and Shehla Pervin $3,4,5,6^{*}$

\begin{abstract}
Background: Breast cancer is a complex heterogeneous disease where many distinct subtypes are found. Younger African American (AA) women often present themselves with aggressive form of breast cancer with unique biology which is very difficult to treat. Better understanding the biology of AA breast tumors could lead to development of effective treatment strategies. Our previous studies indicate that AA but not Caucasian (CA) triple negative (TN) breast cancer cells were sensitive to nitrosative stress-induced cell death. In this study, we elucidate possible mechanisms that contribute to nitric oxide (NO)-induced apoptosis in AA TN breast cancer cells.

Methods: Breast cancer cells were treated with various concentrations of long-acting NO donor, DETA-NONOate and cell viability was determined by trypan blue exclusion assay. Apoptosis was determined by TUNEL and caspase 3 activity as well as changes in mitochondrial membrane potential. Caspase 3 and Bax cleavage, levels of Cu/Zn superoxide dismutase (SOD) and Mn SOD was assessed by immunoblot analysis. Inhibition of Bax cleavage by Calpain inhibitor, and levels of reactive oxygen species (ROS) as well as SOD activity was measured in NO-induced apoptosis. In vitro and in vivo effect of NO treatment on mammary cancer stem cells (MCSCs) was assessed.

Results and discussion: NO induced mitocondria-mediated apoptosis in all AA but not in CA TN breast cancer cells. We found significant TUNEL-positive cells, cleavage of Bax and caspase-3 activation as well as depolarization mitochondrial membrane potential only in AA TN breast cancer cells exposed to NO. Inhibition of Bax cleavage and quenching of ROS partially inhibited NO-induced apoptosis in AA TN cells. Increase in ROS coincided with reduction in SOD activity in AA TN breast cancer cells. Furthermore, NO treatment of AA TN breast cancer cells dramatically reduced aldehyde dehydrogenase1 (ALDH1) expressing MCSCs and xenograft formation but not in breast cancer cells from CA origin.
\end{abstract}

Conclusions: Ethnic differences in breast tumors dictate a need for tailoring treatment options more suited to the unique biology of the disease.

Keywords: Breast cancer, Health disparity, African American, Unique biology

* Correspondence: shehlapervin@cdrewu.edu; spervin@mednet.ucla.edu

${ }^{3}$ Charles R. Drew University of Medicine and Science, Los Angeles, CA 90059,

USA

${ }^{4}$ Department of Obstetrics and Gynecology, David Geffen School of Medicine

at UCLA, Los Angeles, CA 90095, USA

Full list of author information is available at the end of the article 


\section{Background}

Breast cancer is a complex disease where heterogeneous cell types contribute to its initiation and progression $[1,2]$. It has been broadly classified into estrogen receptor positive $(E R+)$ and estrogen receptor negative (ER-) sub types, each of which are dependent on specific environmental cues and signaling pathways for their development [3]. Frequent diagnosis of aggressive triple negative (TN) (ER-, progesterone receptor negative (PR-) and Her2 Neu-) form of breast cancer in young African American (AA) women suggest disparity in development of this deadly disease $[4,5]$. Limited treatment options for these aggressive TN breast tumors causes high mortality rates in AA women [6]. In sharp contrast, Caucasian (CA) women are usually postmenopausal when they develop ER+ or TN breast tumors, which usually have better prognosis and lower mortality rates when compared to AA patients [7]. Even after adjustments for socio-economic factors, AA breast tumors appear to exhibit specific aggressive characteristics suggesting existence of unique biology contributed both by tumor cells and host microenvironment [8].

Using laser capture microdissection and genome-wide mRNA expression analysis, it has been reported that stroma of AA breast tumors had higher inflammation and angiogenesis when compared to similar tumors from the Caucasian populations [9]. In addition, several cell cycle regulators like p16, CCNA2, CCNB1 and CCNE2 as well as several biological processes including endoplasmic reticulum (ER)-associated degradation was found much higher in the tumor epithelium of AA than in the CA populations [9]. Ethnic differences were found in the increased expression of AMFR, a candidate oncogene that promotes metastasis, in AA when compared to CA breast tumors [9]. Furthermore, a tumor suppressor CDH13, was found hyper-methylated in AA when compared to CA breast tumors [10].

Our previous studies have indicated that AA and CA breast cancer cells respond differently to nitrosative stress, which is induced by nitric oxide (NO), a pleiotropic molecule that is produced by nitric oxide synthase (NOS) [11-13]. Oxidative/nitrosative stresses, which are produced by reactive oxygen species (ROS) / reactive nitrogen species (RNS) respectively influence all subtypes of breast cancer $[14,15]$. Both endothelial nitric oxide synthase (eNOS) as well as inducible nitric oxide synthase (iNOS) have been detected in a large number of human breast tumors, where their expression patterns correlate with tumor grades [16]. However, ethnic differences in expression of NOS and response of AA and CA breast cancer cells to oxidative/nitrosative stress remains understudied. We have previously reported that AA TN breast cancer cell line, MDA-MB-468, was highly sensitive to NO-induced apoptosis [17]. NO was able to up regulate MAP kinase phosphatase (MKP-1) expression in MDA-MB-468 cells that promoted inactivation of ERK1/2, Bax integration into mitochondrial membrane leading to caspase- 9 and -3 activation $[17,18]$. However, NO was unable to increase MKP-1 expression or induce apoptosis in MDA-MB-231, a CA TN breast cancer cell line [17]. On the other hand, low (nM) concentrations of NO significantly up regulated proliferation of MDA-MB231 cells by increasing translation of cyclin D1 and ornithine decarboxylase [19]. In this study, we have further examined responses of three additional TN breast cancer cell lines, from each of the ethnic populations, to nitrosative stress. Consistent with our previous studies, we found striking differences between AA and CA TN breast cancer cell lines towards nitrosative stress. NO specifically inactivated superoxide dismutase (SOD) to increase ROS that partly contributed to apoptosis in AA TN breast cancer cell lines. More importantly, NO treatment of AA breast cancer cell lines reduced mammary cancer stem cell (MCSC) content in vitro and attenuated xenograft formation in vivo. Our studies therefore, provide further evidence that there are ethnic differences in the biology of TN breast tumors and specific players in each population should be targeted for effective therapeutic interventions.

\section{Methods \\ Materials}

DETA-NONOate was purchased from Cayman Biochemicals (Ann Arbor, MI), Calpain Inhibitor III was from Calbiochem (Darmstadt, Germany), and N-acetyl-l-cysteine (NAC) was purchased from Sigma Aldrich (St. Louis, MO). Ac-DEVD-AMC was purchased from Pharmingen (San Diego, CA, USA). ApoAlert DNA Fragmentation Assay kit was obtained from Clontech (Mountain View, CA). SOD activity was measured by using an assay kit obtained from Cayman Chemical Company (Ann Arbor, MI). Aldetect Lipid Peroxidation Assay Kit was from Enzo Life Sciences (Ann Arbor, MI, USA). MitoTracker Red CMX-Ros dye was obtained from Life Technologies (Grand Island, NY).

\section{Human cell lines}

All human breast cancer cell lines were obtained from American Type Culture Collection (ATCC) (Manassas, VA) in 2013. ATCC uses Promega PowerPlex 1.2 system and the Applied Biosystems Genotyper 2.0 software for analysis of amplicon. We have not done any further testing in our lab. MDA-MB-231, MDA-MB-157 and MDAMB-436 breast cancer cell lines were propagated in Leibovitz's L-15 medium containing 10 \% FBS. HCC1806, HCC-70, MDA-MB-468 and HCC-1395 were propagated in RPMI 1640 containing $10 \%$ FBS. BT-549 was propagated in DMEM F-12 containing 10 \% FBS. 


\section{Cell viability}

Cells seeded in six-well plate $\left(7.5 \times 10^{5}\right.$ per well $)$ were allowed to grow overnight. The cells treated with various concentrations of DETA-NONOate for $24 \mathrm{~h}$ were collected, and viability was determined by trypan blue exclusion method. The number of viable cells at each concentration and time point was determined in triplicate with a hemacytometer [20].

\section{TUNEL assay}

The TUNEL assay was performed using ApoAlert DNA Fragmentation Assay kit from Clontech as described previously [21]. Briefly, cells $\left(2 \times 10^{5}\right)$ were plated in 6 well plates, fixed in $1 \%$ formaldehyde-PBS at $4{ }^{\circ} \mathrm{C}$ for $20 \mathrm{~min}$. The cells were washed with PBS, and stored overnight in $70 \%$ ethanol. The cells were treated with nucleotide mixture containing terminal deoxynucleotidyltransferase (Tdt) enzyme and incubated at $37{ }^{\circ} \mathrm{C}$ for $1 \mathrm{~h}$. Cells were washed and analyzed under fluorescent microscope.

\section{Caspase-3 assay}

Cells were lysed in insect cell lysis buffer $\{50 \mathrm{~mm}$ HEPES, 100 mM NaCl, 2 mM EDTA, 0.1 \% 3-[(3-cholamidopropyl)dimethylammonio]-1-propanesulfonic acid (CHAPS), $10 \%$ sucrose, $5 \mathrm{mM}$ DTT, and $1 \times$ protease inhibitor\} for $30 \mathrm{~min}$ at $4{ }^{\circ} \mathrm{C}$. The lysates were used for caspase-3 (3 $\mu \mathrm{g})$ assay using Ac-DEVD-AMC substrate, which after specific cleavage releases fluorescent AMC that was quantified using a fluorometer (Versa Fluro; Bio-Rad) with excitation at $380 \mathrm{~nm}$ and emission at 440 $\mathrm{nm}$ as described previously [22].

\section{Western analysis}

For analysis of cytosolic proteins, cells were lysed in cell lysis buffer [50 mm HEPES (pH 7.5); 1 mm DTT, 150 mM NaCl, 1 mM EDTA, 0.1 \% Tween 20, 10 \% glycerol, $10 \mathrm{~mm} \beta$-glycerophosphate, $1 \mathrm{mM} \mathrm{NaF}, 0.1 \mathrm{~mm}$ orthovanadate, $10 \mu \mathrm{g} / \mathrm{ml}$ leupeptin, $10 \mu \mathrm{g} / \mathrm{ml}$ aprotinin, and $0.1 \mathrm{mM}$ PMSF] and were incubated at $4{ }^{\circ} \mathrm{C}$ for $30 \mathrm{~min}$. Protein concentration was measured using Bio-Rad protein assay dye concentrate. Lysates $(30 \mu \mathrm{g})$ were resolved electrophoretically on $10 \%$ SDS-polyacrylamide gel and electrotransferred to a polyvinylidine difluoride membrane (Bio-Rad) using a tank blot procedure (Bio-Rad Mini Protean II). The membranes were incubated with the following primary antibodies: Heme oxygenase-1 (HO-1) (Santa Cruz, Cat \# sc-10789), cleaved caspase-3 (Cell Signaling, Cat \# 9661), Bax (Santa Cruz Biotechnologies, Cat \# 20067), Bcl2 (BD-Transduction Laboratories, Cat \# 551052), $\beta$-actin (Cell Signaling Technologies, Cat \# 4967), NOX4 (Abcam, Cat \# ab60940), Mn-SOD (Abcam, Cat \# 13533), Cu/Zn SOD (Abcam, Cat \#13498), COX IV (Abcam, ab14744) and 1:1000 dilutions of respective horseradish peroxidase-linked $\mathrm{F}(\mathrm{ab})$ fragment secondary antibody (Amersham Corp.,
Piscataway, NJ) for $1 \mathrm{~h}$. Immunoreactive bands were visualized by enhanced chemiluminescence (ECL) detection system (Amersham) as described previously $[20,22]$.

\section{Measurement of MMP by flow cytometry}

Cells $\left(1 \times 10^{6}\right)$ were harvested after various treatments, washed twice with cold 1xPBS and incubated with 100 nM MitoTracker Red CMX-Ros dye at $37{ }^{\circ} \mathrm{C}$ for $15 \mathrm{~min}$ in the dark, washed twice with cold PBS, and analyzed immediately by flow cytometry, as described previously [20].

Measurements of malondialdehyde and 4-hydroxy-alkenals Levels of malondialdehyde and 4-hydroxy-alkenals (4-HAE) was measured using Aldetect Lipid Peroxidation Assay Kit (cat \# BML-AK170-0001, Enzo Life Sciences, Ann Arbor, MI, USA) as per manufacturer's instructions, described previously [23].

\section{Mitochondria and cytosolic cell fractionation}

The cell fractionation was performed using mitochondria and cytoplasmic extraction reagents from Thermo Scientific (Rockford, IL, USA). The fractionation was done as described previously [17].

\section{Superoxide dismutase activity assay}

Cells $\left(1 \times 10^{6}\right)$ were seeded in six well plates to confluence and collected without use of proteolytic enzyme. SOD activity was measured by using an assay kit obtained from Cayman Chemical Company (Ann Arbor, MI). The activity assay was performed according to the manufacturer's protocol.

\section{Aldefluor assay and flow cytometry}

Aldefluor assay was carried out as described previously $[24,25]$ according to manufacturer's (cat \# 01700, Stem cell Technologies, Vancouver, Canada) guidelines. Briefly, breast cancer cells were suspended in Aldefluor assay buffer containing an ALDH substrate, bodipyaminoacetaldehyde (BAAA) at $1.5 \mu \mathrm{M}$, and incubated for $40 \mathrm{~min}$ at $37^{\circ} \mathrm{C}$. To distinguish between $\mathrm{ALDH}^{+}$and $\mathrm{ALDH}^{-}$cells, a fraction of cells was incubated under identical condition in the presence of a 10 -fold molar excess of the ALDH inhibitor, diethyl amino benzaldehyde (DEAB). This results in a significant decrease in the fluorescent intensity of $\mathrm{ALDH}^{+}$cells and was used to compensate the flow cytometer. To determine CD44 expression, MDA-MB-231 and HCC1806 cells suspended in $\mathrm{PBS}$ were exposed to $\mathrm{PE}$ conjugated anti-human CD44 antibody (cat \# 555479, BD Pharmingen ${ }^{\mathrm{TM}}, \mathrm{CA}$, USA) and subjected to flow cytometry analysis.

\section{Xenograft formation}

Six to eight week old nude mice (Harlan Laboratories Inc. Indianapolis, IN) were used for xenograft engraftment. 
Control or DETA-NONOate treated (24h) MDA-MB-468, HCC-70, HCC-1806 and MDA-MB-231 cells ( $2 \times 10^{6}$ cells/ $100 \mu \mathrm{l})$ were mixed with matrigel (1:1) and implanted subcutaneously (posterior dorsolateral) in the nude mice. Tumors were monitored over a period of 15 weeks and tumor volume was calculated as described previously $[24,26]$. This study was carried out in strict accordance with the recommendations in the Guide for the Care and Use of Laboratory Animals of the National Institutes of Health. The protocol was approved by the Institutional Animal Care and Use Committee on the Ethics of Animal Experiments of the Charles R. Drew University of Medicine and Science (permit number: I-1103-261).

\section{Statistical analysis}

Data are presented as mean \pm S.D. and between-group differences were analyzed using ANOVA. If the overall ANOVA revealed significant differences, then pairwise comparisons between groups were performed by Newman-Keuls multiple comparison test. All comparisons were two-tailed, and $p$-values $<0.05$ were considered statistically significant. The experiments were repeated at least three times, and data from representative experiments are shown.

\section{Results}

\section{Nitric Oxide preferentially induced cell death in AA TN} breast cancer cells

Effect of NO on viability and proliferation of breast cancer cell was examined by treatment with various concentrations of DETA NONOate, a long acting NO-donor. We analyzed four different breast cancer cell lines obtained from each of the ethnic populations. AA (HCC-1806, HCC-70, MDA-MB-157 and MDA-MB-468) and CA (BT-549, MDA-MB-436, HCC-1395 and MDA-MB-231) breast cancer cell lines were treated with various concentrations of DETA-NONOate for different time points. We and others have previously demonstrated that lower concentrations $(1-100 \mu \mathrm{M})$ of DETA-NONOate released physiological range $(\mathrm{nM})$ while at higher concentrations $(0.2-1 \mathrm{mM})$ released high pathophysiological range $(\mu \mathrm{M})$ of NO respectively $[27,28]$. In this study, we observed that DETA-NONOate at 50 $\mu \mathrm{M}$ induced (HCC-1806: $19.37 \pm$ $2.58 \%$; MDA-MB-468: $43.94 \pm 1.26 \%$ ); $100 \mu \mathrm{M}$ (HCC1806: $17.21 \pm 0.18 \%$; MDA-MB-468: $47.01 \pm 0.36 \%)$;

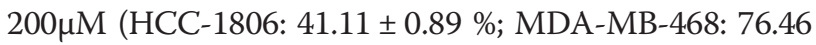
$\pm 1.25 \%$ ); and $300 \mu \mathrm{M}$ (HCC-1806: $23.54 \pm 0.27 \%$; MDAMB-468: $84.78 \pm 0.58 \%$ ) cell death at 48 h (Fig. 1a). In addition, high $\mathrm{NO}$ at $48 \mathrm{~h}$. induced significantly higher cell death at $500 \mu \mathrm{M}$ (HCC-70: $52.10 \pm 5.76 \%$; HCC-1806: $82.84 \pm 3.36 \%$; MDA-MB-468: $95.35 \pm 1.82 \%$; and MDAMB-157: $94.71 \pm 1.71 \%)$ and at $1 \mathrm{mM}$ (HCC-70: $84.72 \pm$ 1.83 \%; HCC-1806: $92.80 \pm 2.98$ \%; MDA-MB-468: 96.66 $\pm 1.57 \%$; and MDA-MB-157: $99.23 \pm 0.769 \%$ ) (Fig. 1b). In all the four CA cell lines, no apparent cell death was observed at low concentrations of NO, while at high concentrations only $20-28 \%$ cell death was observed at $48 \mathrm{~h}$ in both MDA-MB-231 (27.07 $\pm 4.56 \%)$ and MDA-MB-436 $(27.19 \pm 5.57 \%)$ cancer cells (Fig. 1b). Even at $24 \mathrm{~h}, 1 \mathrm{mM}$ DETA-NONOate was able to induce significant cell death selectively in AA TN breast cancer cells (HCC-70: $40.00 \pm$ 3.99 \%; HCC1806: $46.23 \pm 3.42 \%$; and MDA-MB-468: $98.14 \pm 0.66 \%$ ), while no significant cell death was observed in CA cells (Fig. 1c). We further performed terminal deoxynucleotidyl transferase dUTP nick end labeling (TUNEL) assay to assess whether DNA fragmentation occurred in TN AA breast cancer cells after 24 and $48 \mathrm{~h}$ of DETA-NONOate treatments. There was a significant increase in TUNEL-positive cells in AA but not in CA breast cancer cell line following DETA-NONOate $(1 \mathrm{mM})$ treatment (Fig. 1d-e). Quantitative analysis of TUNEL-positive cells in MDA-MB-468 cells showed significant increase at both $24 \mathrm{~h}(28.71 \pm 4.49 \%)$ and $48 \mathrm{~h}$ $(43.27 \pm 7.78 \%)$ (Fig. 1e). No significant increase of TUNEL-positive cells were found in MDA-MB-231 cells at both time points following similar treatments (Fig. 1e). As DNA fragmentation is a hallmark of cells undergoing apoptosis where caspase- 3 is the main executioner enzyme [29], we simultaneously examined caspase- 3 activity in TUNEL-positive AA TN cells treated with NO. We found increased caspase- 3 activity in AA TN cells (HCC1806 and MDA-MB-468) with 1mM DETA-NONOate treatment as early as $24 \mathrm{~h}$, while no increase in activity was found in CA TN cells (Fig. 1f). Since the breast cancer cells from CA did not undergo apoptosis with NO treatment, we further examined the induction of $\mathrm{HO}-1$, which is an early stress response marker [30]. We were able to detect early (8h after treatment) up-regulation of $\mathrm{HO}-1$ protein levels in all the AA cell lines examined, while no significant change was found in CA TN breast cancer cells (Fig. 1g). These data indicate that NO increased cell death due to apoptosis in AA, while no detectable response was observed in CA TN breast cancer cells.

\section{NO induced mitochondria-mediated apoptosis in AA TN breast cancer cells}

We further examined whether mitochondria was involved in NO-induced apoptosis in AA TN breast cancer cells. Integrity of mitochondrial membrane, which is maintained by the ratio of pro- apoptotic and anti-apoptotic proteins, releases cytochrome $C$ when compromised to activate caspase-3 [31]. Cleaved Bax, a pro-apoptotic molecule, has been found to integrate into the mitochondrial membrane to release cytochrome $C$ [17]. Cleaved caspase- 3 as well as cleaved Bax, which is an active form of Bax, was detected in all AA but not in CA TN breast cancer cells with $48 \mathrm{~h}$ of DETA-NONOate (1mM) treatment (Fig. 2a-b). Interestingly, basal levels of $\mathrm{Bcl} 2$, an anti-apoptotic molecule was 


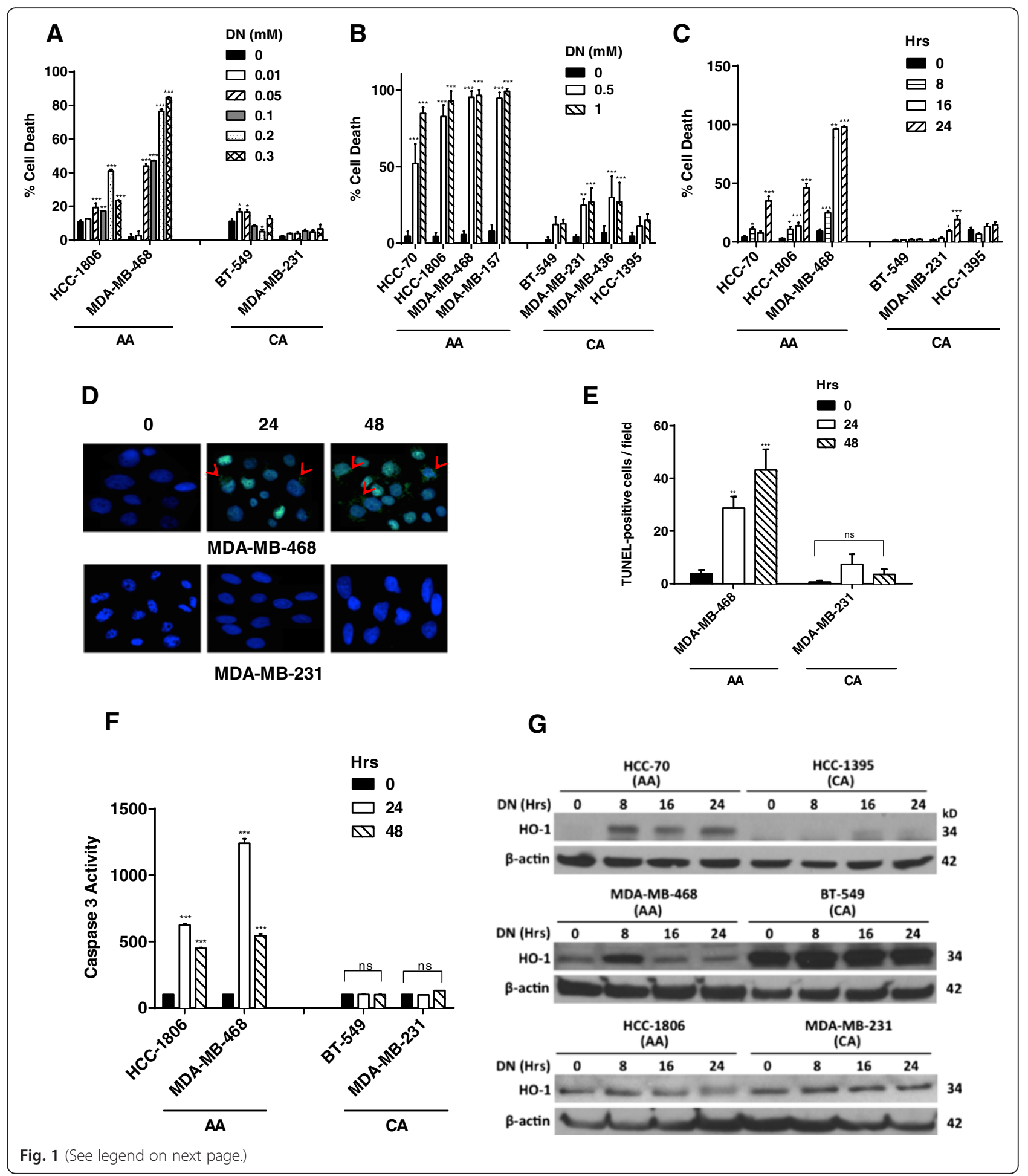


(See figure on previous page.)

Fig. 1 Nitric oxide preferentially induced cell death in AA breast cancer cells. AA and CA breast cancer cell lines were propagated in their respective media and treated with various concentrations of a) DETA-NONOate (DN)(0.01-0.3mM) for 48h. b) DETA-NONOate (0.5-1mM) for 48h c) DETA-NONOate $(1 \mathrm{mM})$ for 8-24h. Following these various treatments, the cells were harvested and their viability was determined by trypan blue exclusion method using hemocytometer for cell counting. d) Cells propagated on 8 well chamber slides were treated with DETA NONOate $(1 \mathrm{mM})$ for 24 and $48 \mathrm{~h}$. After these treatments the cells were fixed with 4\% paraformaldehyde for 30 mins and DNA fragmentation determined by performing TUNEL assay. A representative picture of control and TUNEL positive MDA-MB-468 and MDA-MB-231 cells are shown. e) Quantitation of TUNEL positive cells was performed on images taken at $100 \times$ magnification. Number of TUNEL positive cells/field (average of 3 fields) for each time points/cell line is shown. f) Cells treated with DETA-NONOate (1 mM) for $48 \mathrm{~h}$ were lysed in insect cell lysis buffer and $3 \mu \mathrm{g}$ of total cell lysates were subjected to caspase-3 activity assay using florescent substrates. Results from 3 different experiments were represented. g) Immunoblot

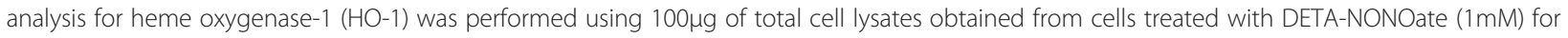
various time points (0-24h). We used $\beta$-actin as housekeeping control. Two way ANOVA statistics was performed for A, B, C, E and F. Data are represented as mean \pm SD with significant values presented as ${ }^{*} p<0.01,{ }^{* *} p<0.001,{ }^{* *} p<0.0001$

undetectable in HCC-1806, while its levels dramatically declined in MDA-MB-468 and MDA-MB-157 AA TN breast cancer cells with $\mathrm{NO}$ treatment (Fig. 2a-b). In sharp contrast, significant $\mathrm{Bcl} 2$ levels were detected in all CA TN breast cancer cells and remained relatively stable or even slightly increased upon NO exposure (Fig. 2a-b). Since Bax cleavage was a common occurrence in all AA $\mathrm{TN}$ cells undergoing apoptosis, we inhibited Bax cleavage to examine its contribution to NO-induced apoptosis. Calpain, which gets activated by oxidative stress, cleaves Bax at the N-terminal to generate a potent pro-apoptotic $18-\mathrm{kDa}$ fragment that promotes Bcl-2-independent cytochrome $C$ release and apoptotic cell death [32]. We found that pretreatment with Calpain inhibitor III caused 52.74 \pm $4.56 \%$ reduction in cell death with $\mathrm{NO}$ treatment in HCC-1806 AA TN breast cancer cells as assessed by trypan blue exclusion assay (Fig. 2c). No change in cell viability was observed in NO treated CA breast cancer cells with or without Calpain inhibitor III. Immunoblot analysis shows that in addition to reduction in cell death, there was reduced Bax and caspase-3 cleavage with Calpain inhibitor III treatment in AA but not in CA breast cancer cells (Fig. 2d-e).

Apoptotic stimuli initiates a series of changes in the mitochondria that are crucial to the death program [33, 34]. One of the changes is opening of large pores in the mitochondrial membrane leading to mitochondrial permeability transition (PT) and disruption in the mitochondrial membrane potential (MMP), which are early obligatory step in the death program [35]. We, further examined changes in MMP in AA and CA TN breast cancer cells with $\mathrm{NO}$ treatment. We found AA TN breast cancer cells upon NO exposure underwent significant depolarization of MMP as early as $24 \mathrm{~h}$ with further increase at $48 \mathrm{~h}$ (Fig. 2f). On the contrary, with NO treatment, there was hyperpolarization of mitochondrial membranes in CA breast cancer cell lines (Fig. 2f). These data indicate that NO induced mitochondriamediated apoptosis specifically in AA but not CA TN breast cancer cells.

\section{NO increased oxidative stress to induce mitochondria- mediated apoptosis in AA TN breast cancer cells}

$\mathrm{NO}$ has been found to react with ROS, more specifically with superoxide $\left(\mathrm{O}_{2}^{-}\right)$, to generate peroxynitrite and oxidative/nitrosative stress that could contribute to depolarization of MMP and mitochondria-mediated apoptosis [28]. We measured malondialdehyde and 4-hydroxyalkenals, which have been used as an indicator of lipid peroxidation and oxidative stress, in NO treated cells. Concentrated lysates of control and NO treated cells were subjected to colorimetric assay to detect malondialdehyde and 4-hydroxyalkenals using kit and manufacturer's instructions as mentioned in Materials and Method. There was increase in oxidative stress with DETA-NONOate $(1 \mathrm{mM})$ treatment as early as $6 \mathrm{~h}$ in HCC-70 (273.79 $\pm 27.27 \%)$, HCC-1806 $(151.04 \pm 9.38 \%)$, MDA-MB-468 (204.20 $\pm 25.26 \%)$, and MDA-MB-157 (218.87 $\pm 40.07 \%)$ AA TN breast cancer cells (Fig. 3a). No significant increase in oxidative stress was detected in any of the CA TN breast cancer cells examined (Fig. 3a). We further pre-treated AA breast cancer cells with $\mathrm{N}$-acetyl cysteine (NAC), a ROS quencher, to determine whether increase in ROS with NO treatment contributed to apoptosis. Pre-treatment of cells with NAC significantly reduced NO-mediated cell death in HCC-1806 (67.13 \pm $1.57 \%$ ) (Fig. 3b). Immunoblot analysis showed that NOinduced high Bax cleavage in HCC-1806 cells was attenuated by pretreatment with NAC (Fig. 3c). On the contrary in CA TN cell lines, NAC treatment led to slight increase in cell death in a concentration-dependent manner (Fig. 3d). No significant cleavage of Bax was observed in CA breast cancer cells with any of the treatments (Fig. 3e). These data indicate that increased levels of ROS in NO treated AA TN breast cancer may contribute to the observed cell death.

\section{NO inactivated SOD to increase ROS only in AA TN breast cancer cells}

Since NO exposure was able to increase ROS levels in AA $\mathrm{TN}$ breast cancer cells, we further examined the levels of mitochondrial manganese superoxide dismutase (Mn-SOD) and cytosolic copper/zinc SOD (Cu/Zn-SOD). These 


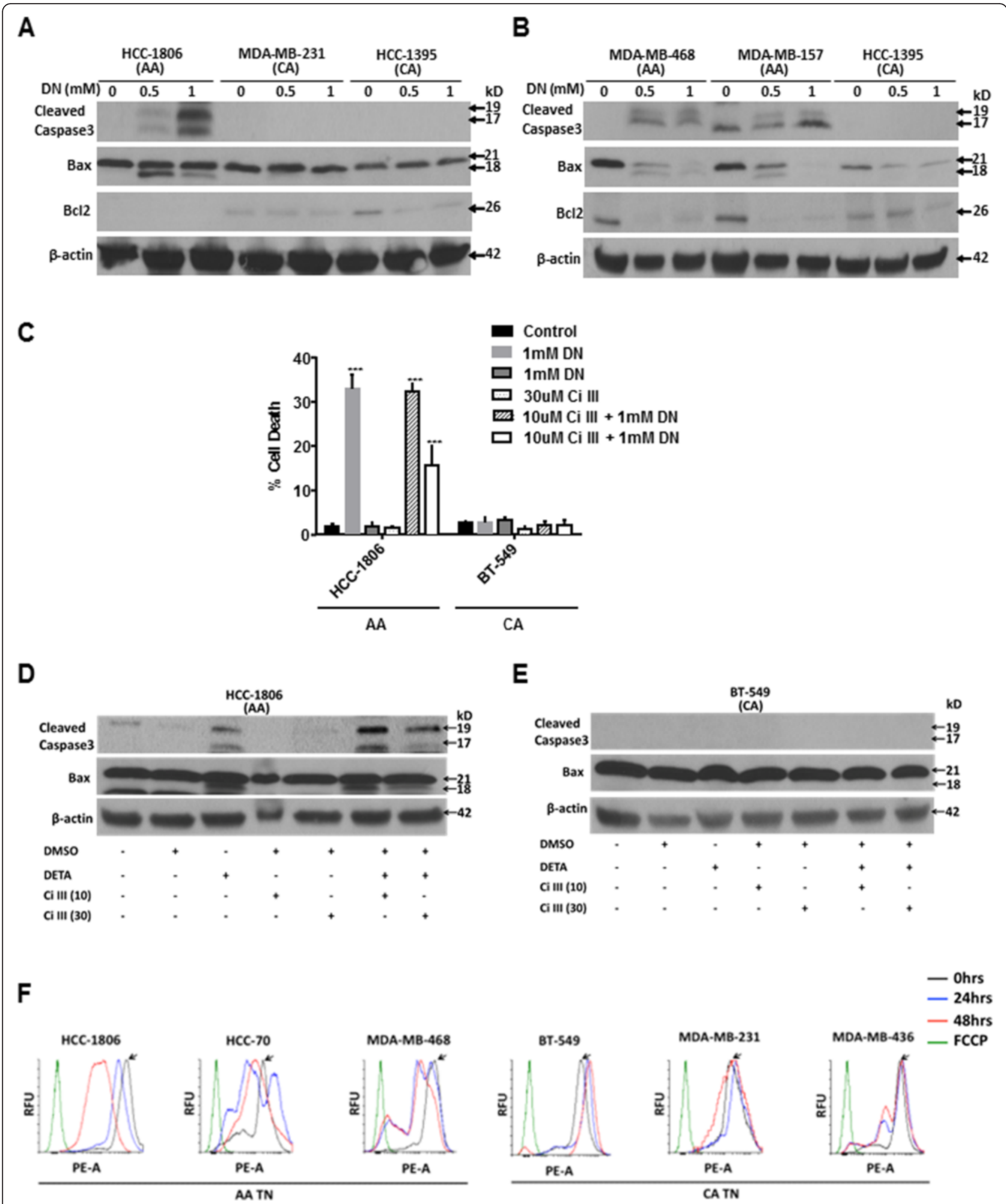

Fig. 2 (See legend on next page.) 


\begin{abstract}
(See figure on previous page.)
Fig. 2 Nitric oxide induced mitochondria mediated apoptosis in AA breast cancer cells. a-b) Cells were seeded to confluence and treated with DETA NONOate (0.5-1 mM) for 48h. Immunoblot analysis was performed for cleaved caspase-3 (19 and 17kDa band), total Bax (Intact Bax 20kD and cleaved Bax 18kD band) and Bcl2. Expression of $\beta$-actin was used as housekeeping control. Neither caspase-3 nor Bax cleavage was found in CA cell lines. c) Cells were exposed with DETA-NONOate $(1 \mathrm{mM})$ with or without pretreatment $(1 \mathrm{~h})$ with various concentrations $(10-30 \mu \mathrm{M})$ of Calpain III (Ci III) inhibitor. Data is presented as mean \pm SD with significant values presented as ${ }^{* * *} p<0.001$. d, e) Cells treated with DETA-NONOate and Calpain inhibitor III were subjected to Immunoblot analysis for cleaved caspase-3 and Bax. f) Cells treated with DETA NONOate for 24h (blue curve) or 48h (red curve) were harvested and incubated with Mito Tracker dye to measure mitochondrial membrane depolarization using flow cytometer. Uncoupling agent carbonyl cyanide-4-(trifloromethoxy) phenyl hydrazine (FCCP) was used as positive control (green curve) while untreated cells served as control (black curve)
\end{abstract}

metalloenzymes are most effective intracellular enzymatic antioxidants, known to hydrolyze $\mathrm{ROS}$ to $\mathrm{H} 2 \mathrm{O} 2$, which further dissociates to $\mathrm{O}_{2}$ and $\mathrm{H}_{2} \mathrm{O}$ [36]. Levels of both SODs were examined after treatment with DETA-NONOate (0.5$1 \mathrm{mM}$ ) for 24 and $48 \mathrm{~h}$. No significant decline in the levels of $\mathrm{Mn}-\mathrm{SOD}$ or $\mathrm{Cu} / \mathrm{Zn} \mathrm{SOD}$ was observed in either AA or CA breast cancer cells at $24 \mathrm{~h}$ of DETA-NONOate treatment (data not shown). However, at 48h, DETA-NONOate (0.5$1 \mathrm{mM}$ ) caused a dramatic reduction in the levels of both $\mathrm{Mn}-\mathrm{SOD}$ and $\mathrm{Cu} / \mathrm{Zn}-\mathrm{SOD}$ in AA but not in CA breast cancer cells (Fig. 4a-c). On the contrary, in some CA cell lines there was an increase in the levels of Mn-SOD (BT-549 and HCC-1395), while in another cell line (MDA-MB-436) there was no significant change from control with $\mathrm{NO}$ treatment (Fig. 4a-c). With cell fractionation, we found considerable amount of Mn-SOD in the mitochondria of CA (BT-549) but not in AA (HCC-70 and HCC-1806) breast cancer cells (Fig. 4d). We did not find any difference in levels of NOX4 protein, which is known to produce ROS, in AA and CA breast cancer cells (Fig. 4a-d). The purity of mitochondria was assessed by examining COX IV protein levels in the mitochondrial fraction (Fig. 4d). Since reduction in the protein levels of SOD at later time points of NO treatment did not coincide with early increase in ROS, we further examined the SOD activity in these cells. We found exposure to NO (DETA NONOate $1 \mathrm{mM}, 48 \mathrm{~h}$ ) reduced SOD activity (HCC-70: $19.15 \pm 7.81$ \%; HCC-1806: $17.22 \pm$ $6.51 \%$ ) in AA breast cancer cells (Fig. 4e). In sharp contrast to decline in AA breast cancer cells, there was some increase in SOD activity in all the CA TN breast cancer cells with NO treatment (BT-549: $3.80 \pm 2.87 \%$; MDA-MB-231: $8.63 \pm 2.06$ ) (Fig. 4e). We further examined SOD activity after shorter exposures to various concentrations of $\mathrm{NO}$ in an AA TN breast cancer cell line (HCC-1806). With lower levels of NO (DETA-NONOate $500 \mu \mathrm{M}$ ) we found a decline in SOD activity as early as $3 \mathrm{~h}(25.01 \pm 9.94 \%)$, which continued to reduce till $8 \mathrm{~h}(72.83 \pm 7.73 \%)$ after which it returned to near control by 16-24h (Fig. 4f). With higher NO (DETA-NONOate $1 \mathrm{mM}$ ), the SOD activity continued to decline till $8 \mathrm{~h}(76.91 \pm 5.2)$ after which it remained lower than the control (Fig. 4g). Since lower concentrations of $\mathrm{NO}$ reduced proliferation of AA breast cancer cell lines, we further examined its effect on Mn SOD and $\mathrm{Cu} / \mathrm{Zn}$ SOD as well as on various proliferation (cyclin D1 and PCNA), apoptosis (Bax and Bcl2), and oxidative stress (NOX4) markers. We did not find changes in the levels of Mn SOD or $\mathrm{Cu} / \mathrm{Zn} \mathrm{SOD}$ in any of the cell lines examined, while the levels of cyclin D1 declined in MDA-MB-468 cells treated with lower concentrations of NO (Fig. 5a, b). In addition, while no significant changes in Bax and Bcl2 was found, there was some decline in NOX4 protein levels in both the cell lines examined. We further examined the stability of these proteins after treating the cells with non-specific protein synthesis inhibitor, cycloheximide, for different time points. No significant changes in the levels of $\mathrm{Cu} / \mathrm{Zn} \mathrm{SOD}$ was observed in MDA-MB-468, MDA-MB-231 and BT549 breast cancer cells, while in HCC-1806 cells, there was an initial decline followed by an increase at later time points of cycloheximide treatment (Fig. 5c-f). In addition, no significant differences in the levels of Mn-SOD with cycloheximide treatment was detected. However the levels of $\mathrm{Bcl} 2$ rapidly declined and remained lower in AA when compared to CA breast cancer cells treated with cycloheximide (Fig. 5c-f). Levels of Bax however remained unchanged in these cells while its cleavage increased at later time points of cycloheximide treatment (Fig. 5c-f). Levels of proliferating cell nuclear antigen (PCNA) remained constant in all the cell lines with cycloheximide treatment (Fig. 5c-f). The above data shows that NO inactivates SOD to increase oxidative stress specifically in AA but not CA $\mathrm{TN}$ breast cancer cells. In addition, there was no significant difference in the stability of Mn-SOD or CU/Zn-SOD in the AA and CA TN breast cancer cells.

\section{NO treatment reduced Mammary Cancer Stem Cell content in AA breast cancer cells}

Mammary cancer stem cells (MCSCs) are a small subset of undifferentiated cells in breast tumors that have been highly implicated in its initiation and progression [37]. Most therapeutic and chemotherapeutic drugs has been found to kill more differentiated cells while MCSCs evade these treatments [38]. Heterogeneity exists within MCSCs populations, which have high aldehyde dehydrogenase 1 (ALDH1) activity and increased expression of CD44, a cell surface marker [39]. There are reports of high expression of ALDH1 in breast tumors in women from African origin [40, 41]. We found high ALDH1 expression in all the $3 \mathrm{AA}$ TN breast cancer cells examined 
A

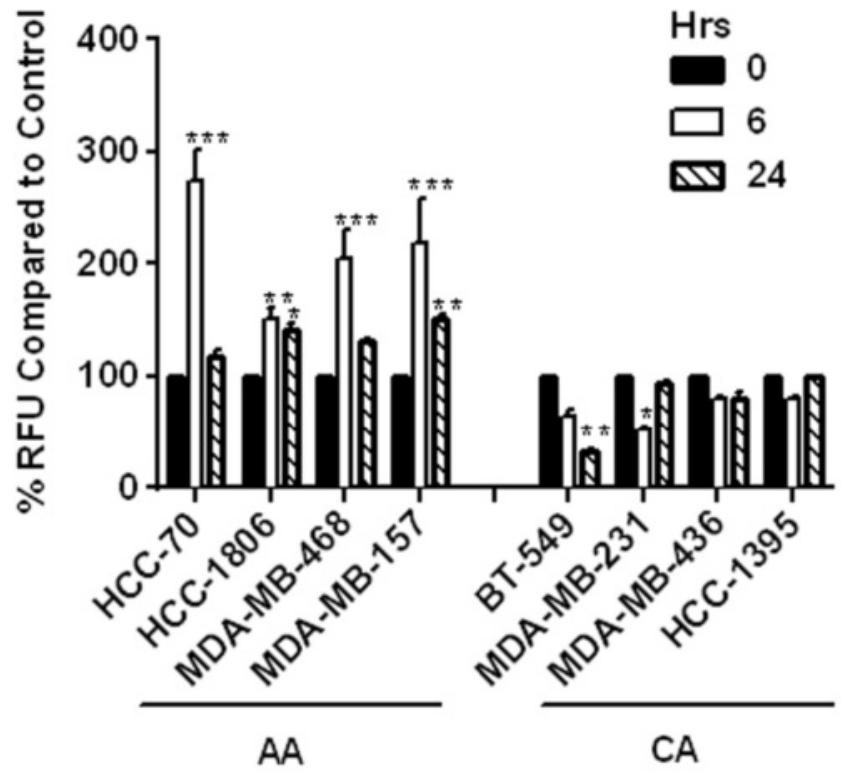

B

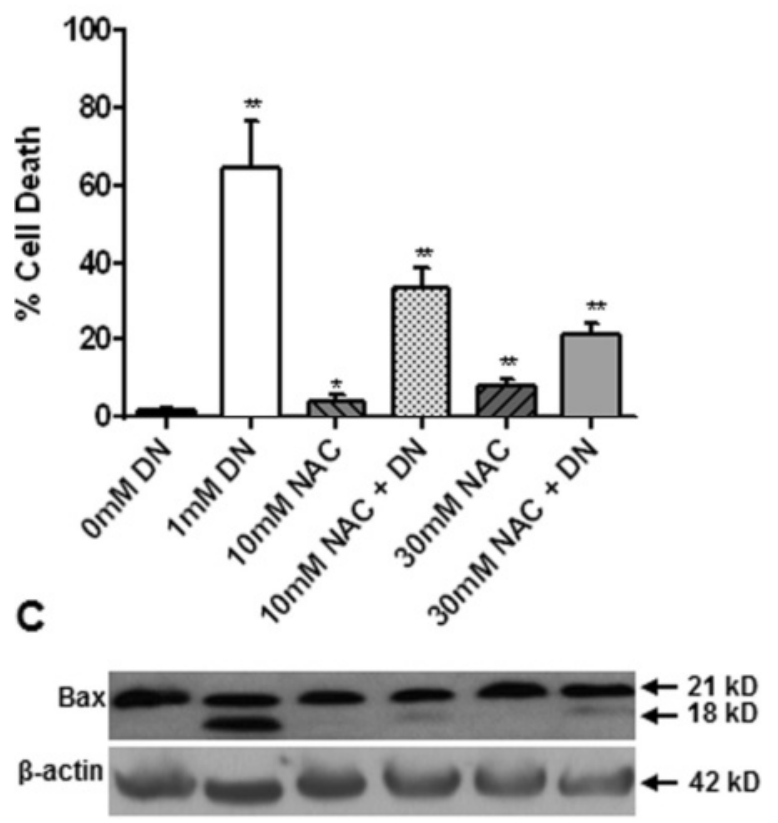

HCC-1806
D
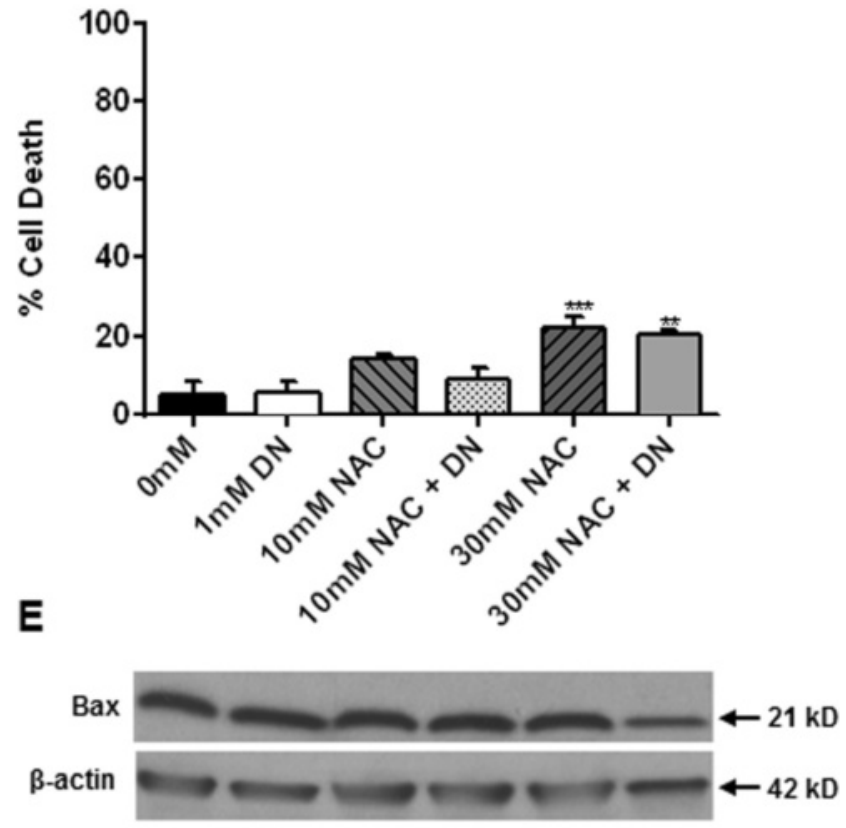

BT-549

Fig. 3 Nitric oxide-induced apoptosis in AA breast cancer cells was dependent on increase in ROS. a) Cells seeded in 96 well plates were treated with DETA NONOate $(1 \mathrm{mM})$ for different time points (6-24h). 4-hydroxy-alkenal levels was measured using Aldetect Lipid Peroxidation Assay kit as per manufacturer's instruction. Cells were seeded to confluence and treated with DETA NONOate $(1 \mathrm{mM})$ for $24 \mathrm{~h}$ with or without pretreatment (1h) with $\mathrm{N}$ acetyl-cysteine (NAC) at various concentrations (10-30mM). b, d) Cell viability was measured by trypan blue exclusion method using hemocytometer for cell counting. c, e) Immunoblot analysis of total cell lysates was performed for Bax (lower panels). Data are represented in Mean \pm SD with significant values presented as ${ }^{*} p<0.01$ and ${ }^{* *} p<0.001$ 


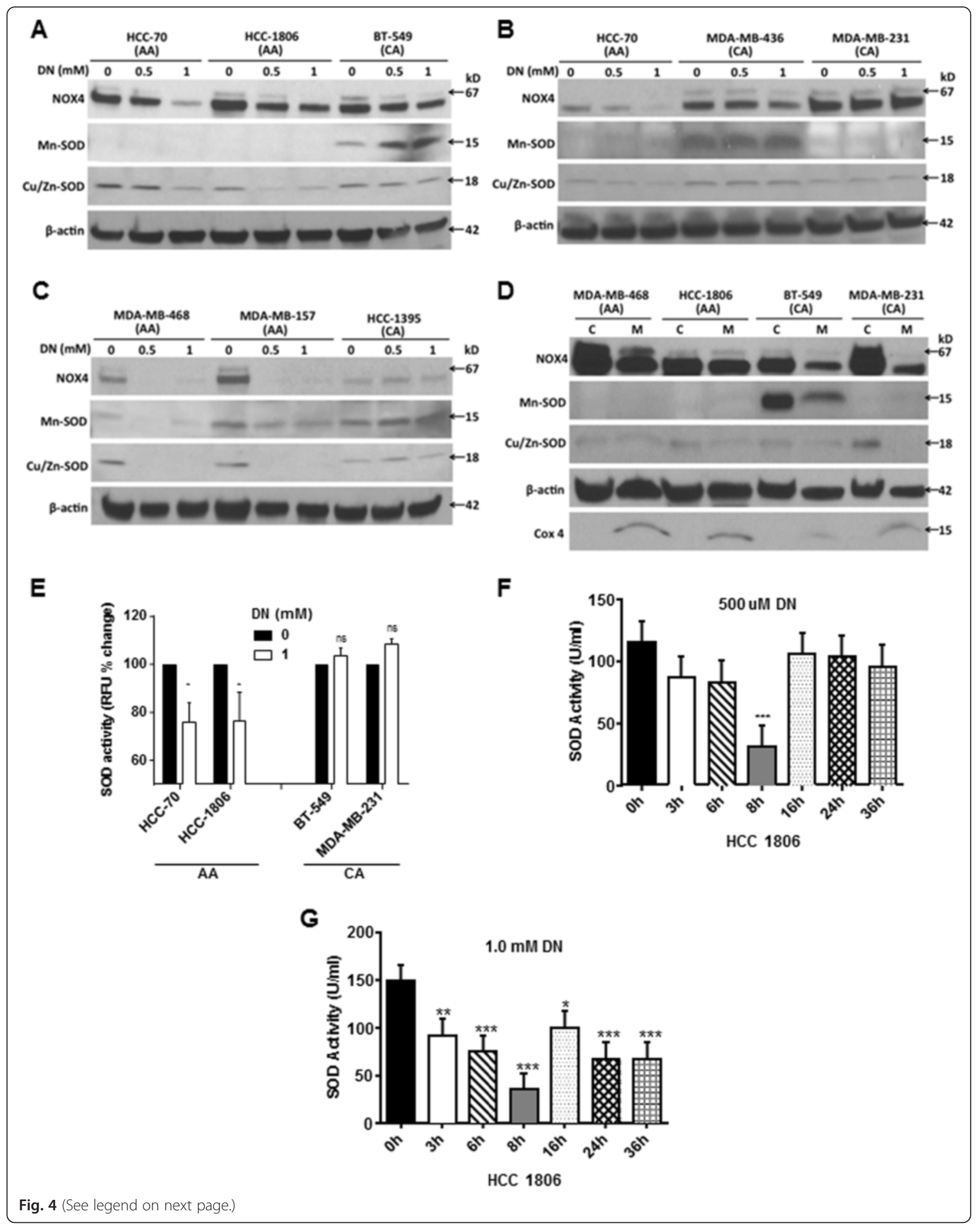


(See figure on previous page.)

Fig. 4 Nitric oxide inactivates SOD to increase ROS in AA TN breast cancer cells. a-c) Cells treated with DETA-NONOate $(0.5 \mathrm{mM}$ and $1 \mathrm{mM})$ for 48h was subjected to immunoblot blot analysis for NOX4, Mn-SOD and Cu/Zn SOD where $\beta$-actin was used as control. d) Control and DETA NONOate $(1 \mathrm{mM})$ treated cells were subjected to cell fractionation using kit to separate cytoplasmic and mitochondrial fraction as per manufacturer's instructions. These fractions were further subjected to immunoblot blot analysis for NOX4, Mn-SOD, and Cu/Zn SOD. COX4 was used as positive control for purity of mitochondrial fraction. $\mathbf{e}, \mathbf{f}, \mathbf{g})$ cells treated with DETA-NONOate $(0.5 \mathrm{mM}$ and $1 \mathrm{mM})$ for various time points (3-36h) were subjected to SOD activity assay using kit as per manufacturer's instructions. Data are represented in Mean \pm SD with significant values presented as ${ }^{*} p<0.01$ and ${ }^{* *} p<0.001$

and NO treatment significantly reduced the expression of ALDH1 in these cells (Fig. 6a). The higher expression of ALDH1 in AA TN breast cancer cells sharply contrasts with its much lower basal expression in CA TN breast cancer cells (Fig. 6a). We however, found much higher CD44 expression in the CA breast cancer cells that further increased with $\mathrm{NO}$ treatment (Fig. 6a). We further confirmed by Western blot that the increase in caspase cleavage in AA TN breast cancer cell lines with NO treatment occurred simultaneously with decrease in MCSC population (data not shown).

We further measured ALDH1 activity in HCC-1806 and HCC-70 after treatment with DETA-NONOate (1mM, 24-36h). We found high basal activity of ALDH1 in HCC1806 (11.8 \%) and HCC-70 (11.3 \%) cells (Fig. 6b-c). Upon $\mathrm{NO}$ exposure there was considerable decline in ALDH1 activity in both the cell lines, HCC-1806 (6.8\%) and HCC-70 (5.6 \%) (Fig. 6b-c). A large amount of dead cells were found in both the cell lines after NO treatment. We were unable to detect any ALDH1 activity in MDA-MB231 cells (Fig. 6d). On the other hand, a large number of MDA-MB-231 cells (17.4\%) expressed CD44, which was undetected in HCC-1806 cells (Fig. 6e-f).

We further examined whether NO treatment of AA and CA breast cancer cells influenced tumor formation in vivo. For this purpose, we implanted control and NO-treated (for 24h) AA and CA TN breast cancer cells $\left(2 \times 10^{6}\right)$ subcutaneously (at a ventro-lateral site) in nude mice and monitored tumor volume for 15 weeks. When compared to the untreated control cells, NO treatment of AA TN breast cancer cells dramatically reduced tumor volume in nude mice (Fig. 6b, c). These results were in sharp contrast to that observed in CA TN breast cancer cells where NO treatment led to formation of larger xenografts when compared to similar treatment groups from AA TN breast cancer cells (Fig. 6d). Our data, therefore, indicate that NO treatment of AA TN breast cancer cells significantly reduce MCSC content and xenograft formation.

\section{Discussion}

Breast cancer in AA women usually have aggressive characteristics and unique biology. In this study, we report that nitrosative stress induced by NO, promoted apoptosis preferentially in all the AA but not in CA TN breast cancer cells. Specifically, NO treatment induced cleavage of pro-apoptotic Bax and an increase in caspase- 3 activity in
AA but not in CA TN breast cancer cells. Interestingly, a decline in anti-apoptotic Bcl2 and depolarization of MMP was observed in AA breast cancer cells. In sharp contrast, $\mathrm{Bcl} 2$ levels remained steady or even increased along with hyperpolarization of MMP in NO treated breast cancer cells of CA origin. There was an early induction of HO-1, a stress response gene, in AA breast cancer cells, which were sensitive to nitrosative stress. Levels of $\mathrm{HO}-1$ did not change in any of the CA cells with NO exposure, further indicating their insensitivity to nitrosative stress. In another study, NO treatment was found to induce higher increase migration and invasiveness of MDA-MB-231 (CA $\mathrm{TN}$ origin) when compared to MDA-MB-468 (AA TN origin) breast cancer cells [42]. It appears that NO elicits tumor promoting responses in CA breast cancer cells that sharply contrasts to the death-promoting signals in AA cells. We have previously shown that low concentrations of $\mathrm{NO}$ in addition to increasing proliferation of MDAMB-231 cells, activated mammalian target of rapamycin (mTOR) to increase translation of proteins [18]. Studies also show that ROS/RNS drive a continuous process of DNA adducts that crosslinks as well as promoting posttranslational modification of lipids and proteins that increase survival, immunosuppression and inhibition of apoptosis [43]. These could be some of the mechanisms by which NO influenced tumor promoting behavior in CA breast cancer cells.

In our study, the basal levels of ROS were comparable in breast cancer cells from the two ethnic populations. However, NO treatment specifically increased ROS only in AA TN breast cancer cells. This increase in ROS coincided with reduction in the activity of total (mitochondrial and cytosolic) SOD in AA TN breast cancer cells. Our study further shows that there was no significant difference in the stability of SOD in AA and CA TN breast cancer cells. There are reports of reduced SOD activity associated with increased nitrosative stress in AAs but not in CA umbilical vein endothelial cells (HUVEC) [44]. Inverse relationship between $\mathrm{NO}$ and SOD activity was also evident in plasma of AA patients suffering from hypertension [45]. Older AA as well as those that underwent spontaneous preterm birth had lower SOD activity when compared to similar group of CA patients [46]. No difference in Mn-SOD Ala-9Val polymorphism in breast tumors from AA and CA patients has been detected [47]. However, a striking 


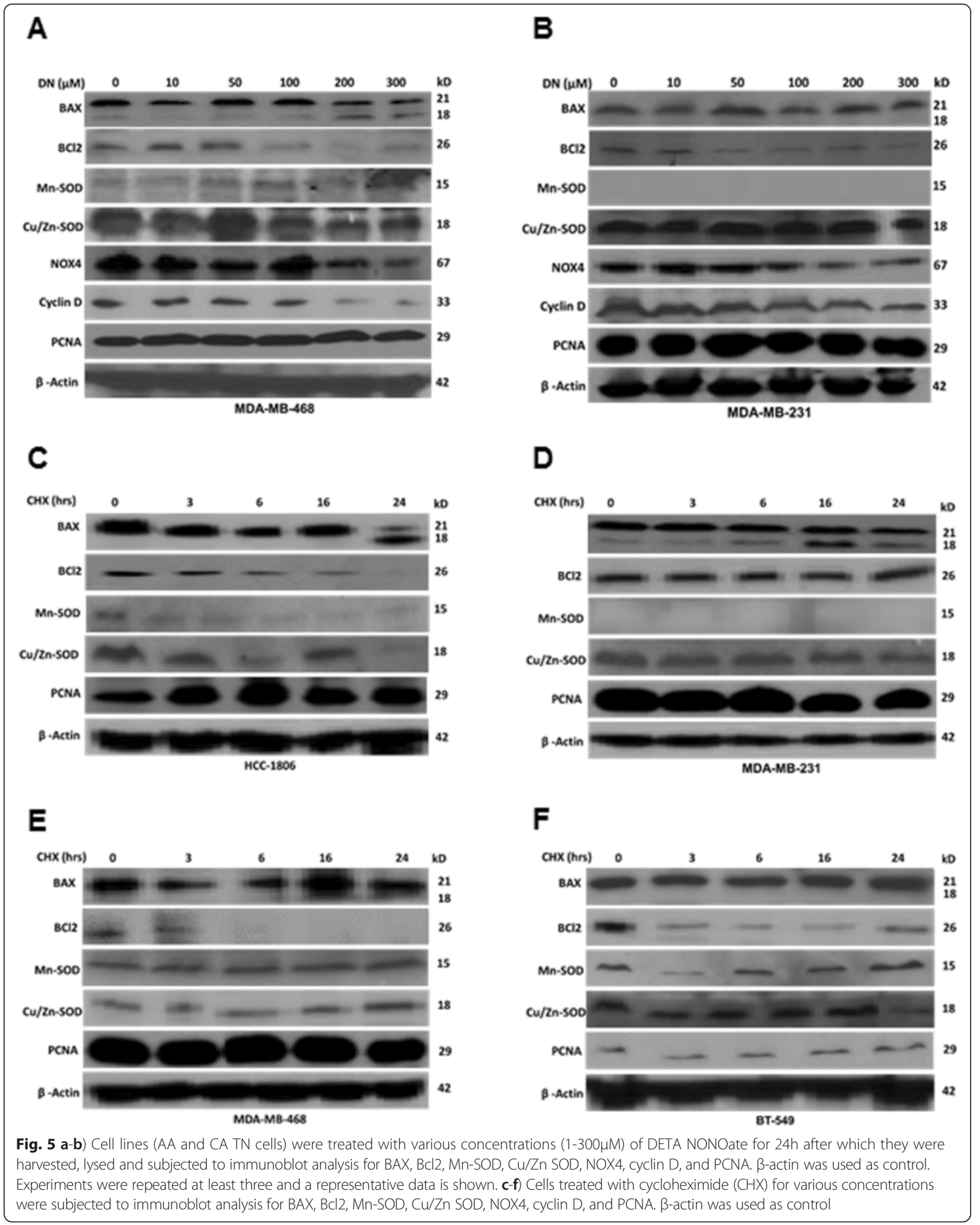




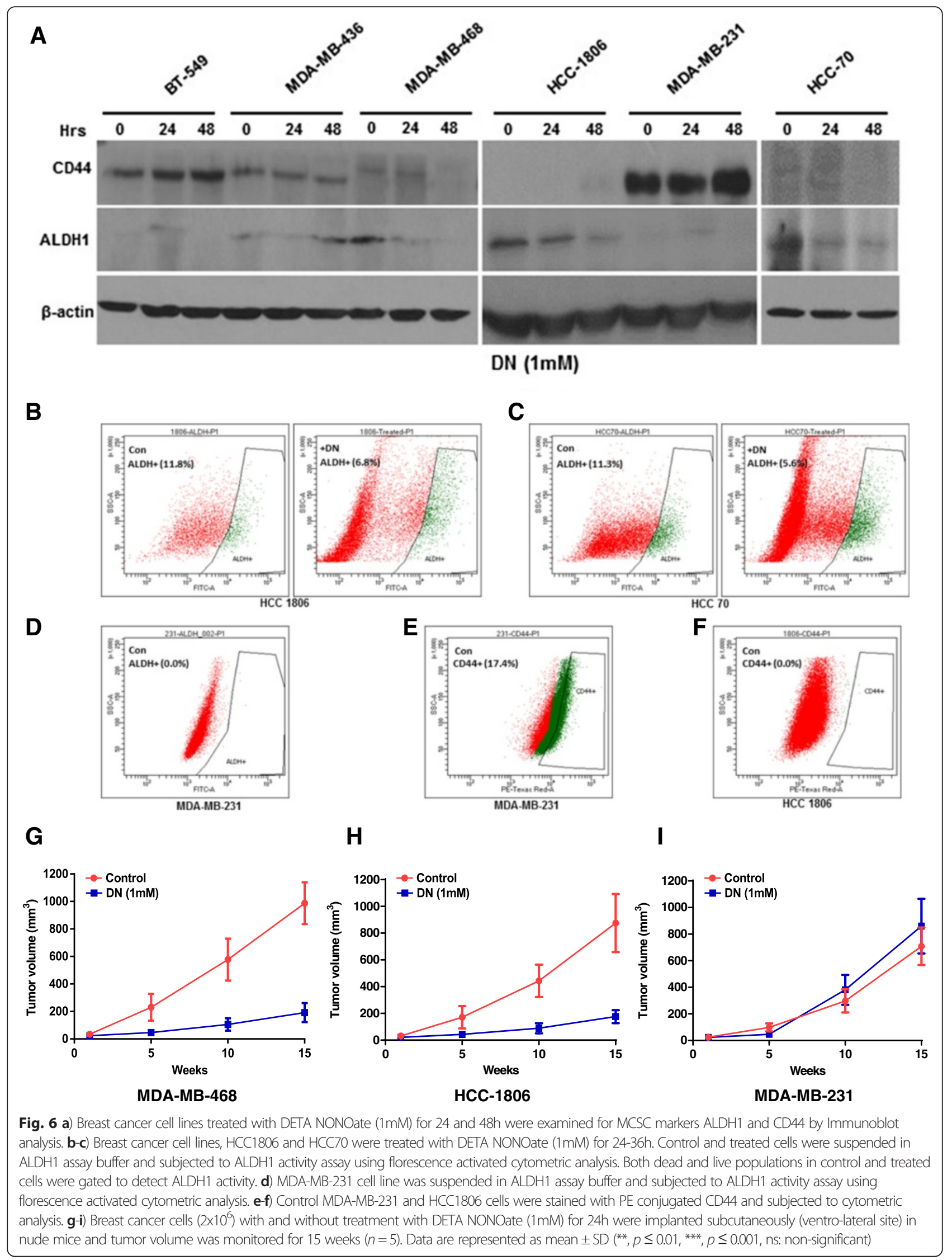


difference in the frequency of 10T/9T intron 3 polymorphism in mitochondrial SOD in AAs has been reported [48]. Although sensitivity of AA population to NO-mediated inactivation of SOD is well demonstrated, molecular mechanisms and consequences of SOD inactivation remain poorly understood.

Prominent differences in the biology of AA and CA breast tumors suggest differences in both the tumor cells and the microenvironment in which these tumors develop. Despite significant differences in biology there is not much difference in the treatment strategies for these tumors. Tumor infiltrating macrophages in poorly differentiated breast carcinoma, express active iNOS that promote angiogenesis, increase tumor size and cause poor survival of patients [16]. More recently, targeting endogenous iNOS in two CA breast cancer cell lines MDA-MB-231 and BT-549, by selective iNOS and pan-NOS inhibitors, was found effective in reducing tumor volume in mouse model [49].

Our previous studies indicate AA TN breast cancer cells utilize arginine preferentially to synthesize polyamines [21,22]. Arginase and nitric oxide synthase (NOS) compete for cellular arginine to produce polyamines and NO respectively [21, 22]. Elevated arginase activity in cells has been found to both decrease cellular availability of NO by competing with NOS to increase L-ornithine. We have shown that arginase expression is up-regulated in AA breast cancer cells, which are dependent on polyamines for survival and proliferation [21]. Therefore exploiting ethnic differences in arginine metabolism has the potential to provide selective druggable targets that could effectively reduce aggressiveness of $\mathrm{CA}$ and $\mathrm{AA}$ TN breast tumors. Although there is ample evidence of unique biology of AA TN breast tumors, no potential druggable target has so far been identified or exploited to reduce the severity of the disease.

The potential of using $\mathrm{NO}$ to induce apoptosis in AA breast tumors appears promising for therapeutic intervention. Depending on the cell type, NO has shown promise as a therapeutic agent to reduce tumor volume [50,51]. The therapeutic potential of NO-donors depends on its capacity to release $\mathrm{NO}$ at optimum concentrations and in a temporally regulated manner to kill tumor cells. A number of potential NO-donors include organic nitrites glyceryl trinitrite (GTN), metal-nitrosyl complexes sodium nitroprusside (SNP), S-nitrosoglutathione (GSNO) and diazeniumdiolates. Studies have shown that GTN induces apoptosis in colon cancer, inhibit hypoxia-mediated metastatic potential of B16F10 murine melanoma cells and increase the chemosensitivity of human prostate tumor xenografts [52-54]. Diethylene diazeniumdiolates (NONOates) has been found to be an effective chemo preventive agent against bone metastatic breast cancer as well as aggressive breast cancer cell lines [55]. Unfortunately, many of these NO-donors lack target specification and controlled release kinetics, therefore cannot be tested for their efficacy in vivo. Considering dual effects of $\mathrm{NO}$ and lack of ideal NO-donors, we are not equipped technically to use NO for therapy.

\section{Conclusions}

AA and CA TN breast cancer cells respond differently to nitrosative stress suggesting differences in their biology. Increased sensitivity of AA TN breast tumors to nitrosative stress-mediated apoptosis suggest exploring the potential of $\mathrm{NO}$ as a therapeutic agent. Therapeutic strategies should be tailored to the unique biology of the disease.

\section{Abbreviations \\ AA, African American; CA, Caucasian; TN, Triple negative; NO, Nitric Oxide; SOD, Superoxide dismutase; ROS, Reactive oxygen species; ALDH1, Aldehyde dehydrogenase 1; MCSCS, Mammary cancer stem cells; ER, Estrogen receptor; PR Progesterone receptor; NOS, Nitric oxide synthase; RNS, Reactive nitrosative stress; MKP-1, MAP kinase phosphatase-1; TUNEL, Terminal deoxynucleotidyl transferase dUTP nick end labeling; HO-1, Hemeoxygenase1; MMP, Mitochondrial membrane potential; PT, Mitochondria permeability transition; NAC, N -acetyl cysteine}

\section{Acknowledgements}

This work was supported by National Institute of Health Grants SC1CA165865 (SP) and SC1AG049682 (RS), and in part by U54MD007598 (RS), and S21MD000103 (RS, SP) grants.

\section{Availability of data and materials \\ Not applicable.}

\section{Authors' contributions}

Study Concept and design: S.P, L.M, R.S. Acquisition of data: L.M, E.T, J.K. Analysis and interpretation of data: S.P, L.M, G.C, R.S. Writing and review of the manuscript: S.P, L.M, G.C, R.S. Study supervision: S.P, R.S. All authors have read and approved the manuscript.

\section{Competing interests}

The authors declare that they have no competing interests.

\section{Consent for publication}

Not applicable.

\section{Ethics approval and consent to participate}

No human subjects were involved for this study. This study was carried out in strict accordance with the recommendations in the Guide for the Care and Use of Laboratory Animals of the National Institutes of Health. The protocol was approved by the Institutional Animal Care and Use Committee on the Ethics of Animal Experiments of the Charles R. Drew University of Medicine and Science (permit number: 1-1103-261). This information has been added in the Methods section page 8 of this manuscript.

\section{Author details}

${ }^{1}$ California State University, Dominguez Hills, Los Angeles, CA, USA. ${ }^{2}$ Columbia University New York, New York, NY 10027, USA. ${ }^{3}$ Charles R. Drew University of Medicine and Science, Los Angeles, CA 90059, USA.

${ }^{4}$ Department of Obstetrics and Gynecology, David Geffen School of Medicine at UCLA, Los Angeles, CA 90095, USA. ${ }^{5}$ Jonsson Comprehensive Cancer Center at UCLA, Los Angeles, CA 90095, USA. ${ }^{6}$ Division of Endocrinology and Metabolism, Charles R. Drew University of Medicine and Science, 1731 East 120th Street, Los Angeles, CA 90059, USA.

Received: 26 January 2016 Accepted: 11 July 2016

Published online: 29 July 2016

\section{References}

1. Polynak K. Heterogeneity in breast cancer. J Clin Invest. 2011;121:3786-88.

2. Koren S, Bentires-Alj M. Breast tumor heterogeneity: source of fitness, hurdle for therapy. Mol Cell. 2015;60:537-46. 
3. Cadoo KA, Fornier MN, Morris PG. Biological subtypes of breast cancer current concepts and implications for recurrence patterns. Q J Nucl Med Mol Imaging. 2013;57:312-21.

4. Carey LA, Perou CM, Livasy CA, Dressler LG, Cowan D, Conway K, Karaca G, Troester MA, Tse CK, Edminston S, Deming SL, Geradts J, Cheang MC, Nielsen TO, Moorman PG, Earp HS, Millikan RC. Race, breast cancer subtypes, and subtypes, and survival in the Carolina Breast Cancer Study. JAMA. 2006;295:2492-502.

5. Kanaan YM, Sampey BP, Beyene D, Esnakula AK, Naab TJ, Ricks-Santi L, Dasi S, Day A, Copeland RL Sr BKWFW, Gabrielson E, Dewitty Jr RL. Metabolic profile of triple-negative breast cancer in African-American women reveals potential biomarkers of aggressive disease. Cancer Genomics Proteomics. 2014;11:279-94

6. Dietze EC, Sistrunk C, Miranda-Carboni G, O'regan R, Seewaldt VL. Triplenegative breast cancer in African-American women: disparities versus biology. Nat Rev Cancer. 2015;15:248-54.

7. Balmanoukian A, Zhang Z, Jeter S, Slater S, Armstrong DK, Emens LA, Fetting JH, Wolff AC, Davidson NE, Jacobs L, Lange J, Tsangaris TN, Zellars R, Gabrielson E, Stearns V. African American women who receive primary anthracycline- and taxane- based chemotherapy for triple-negative breast cancer suffer worse outcomes compared with white women. J Clin Oncol. 2009;27:e35-7.

8. Anders CK, Carey LA. Biology, metastatic patterns, and treatment of patients with triple-negative breast cancer. Clin Breast Cancer. 2009;9 Suppl 2:S73-81.

9. Martin DN, Boersma BJ, Yi M, Reimers M, Howe TM, Yfantis HG, Tsai YC, Williams EH, Lee DH, Stephens RM, Weissman AM, Ambs S. Differences in the tumor microenvironment between African-American and EuropeanAmerican Breast cancerpatients. PLoS One. 2009;4, e4531.

10. Wang S, Dorsey TH, Terunuma A, Kittles RA, AMbs S, Kwabi-Addo B. Relationship between tumor DNA methylation status and patient characteristics in African-American and European-American women with breast cancer. PLoS One. 2012;7, e37928.

11. Espey MG, Miranda KM, Feelisch M, Fukuto J, Grisham MB, Vitek MP, Wink DA. Mechanisms of cell death governed by the balance between nitrosative and oxidative stress. Ann N Y Acad Sci. 2000;899:209-21.

12. Korde SD, Basak A, Chaudhary M, Goval M, Vagga A. Enhanced nitrosative and oxidative stress with decreased total antioxidant capacity in patients with oral precancer and oral squamous cell carcinoma. Oncology. 2011;80:382-89.

13. Seril DN, Liao J, Yang GY. Colorectal carcinoma development in inducible nitric oxide synthase-deficient mice with dextran sulfate sodium-induced ulcerative colitis. Mol Carcinog. 2007;46:341-53.

14. Switzer CH, Ridnour LA, Cheng R, Heinecke J, Burke A, Glynn S, Ambs S, Wink DA. S-Nitrosation mediates multiple pathways that lead to tumor progression in estrogen receptor-negative breast cancer. For Immunopathol Dis Therap. 2012;3:117-24.

15. Das Gupta S, So JY, Wall B, Wahler J, Smolarek AK, Sae-Tan S, Soewono KY, Yu H, Lee MJ, Thomas PE, Yang CS, Suh N. Tocopherols inhibit oxidative and nitrosative stress in estrogen-induced early mammary hyperplasia in $\mathrm{ACl}$ rats. Mol Carcinog. 2015:54:916-25.

16. Ambs S, Glynn SA. Candidate pathways linking inducible nitric oxide synthase to a basal-like transcription pattern and tumor progression in human breast cancer. Cell Cycle. 2011;10:619-24.

17. Pervin S, Singh $\mathrm{R}$, Chaudhuri G. Nitric-oxide-induced Bax integration into the mitochondrial membrane commits MDA-MB-468 cells to apoptosis: essential role of Akt. Cancer Res. 2003:63:5470-9.

18. Pervin S, Singh R, Freije WA, Chaudhuri G. MKP-1-induced dephosphorylation of extracellular signal-regulated kinase is essential for triggering nitric oxide-induced apoptosis in human breast cancer cell lines: implications in breast cancer. Cancer Res. 2003;63:8853-60.

19. Pervin S, Singh R, Hernandez E, Wu G, Chaudhuri G. Nitric oxide in physiologic concentrations targets the translational machinery to increase the proliferation of human breast cancer cells: involvement of mammalian target of rapamycin/elF4E Pathway. Cancer Res. 2007;67:289-99.

20. Pervin $S$, Singh $R$, Gau CL, Edamatsu H, Tamanoi F, Chaudhuri G. Potentiation of nitric oxide-induced apoptosis of MDA-MB-468 cells by farnesyltransferase inhibitor: implications in breast cancer. Cancer Res. 2001; 61:4701-6.

21. Singh R, Pervin S, Wu G, Chaudhuri G. Activation of caspase-3 activity and apoptosis in MDA-MB-468 cells by N(omega)-hydroxy-L-arginine, an inhibitor of arginase, is not solely dependent on reduction in intracellular polyamines. Carcinogenesis. 2001;22:1863-9.

22. Singh R, Pervin S, Karimi A, Cederbaum S, Chaudhuri G. Arginase activity in human breast cancer cell lines: N(omega)-hydroxy-L-arginine selectively inhibits cell proliferation and induces apoptosis in MDA-MB-468 cells. Cancer Res. 2000;60:3305-12.

23. Pervin S, Tran L, Urman R, Braga M, Parveen M, Li SA, Chaudhuri G, Singh R. Oxidative stress specifically downregulates survivin to promote breast tumour formation. Br J Cancer. 2013;108:848-58.

24. Pervin S, Hewison M, Braga M, Tran L, Chun R, Karam A, Chaudhuri G, Norris $K$, Singh R. Down-regulation of vitamin $D$ receptor in mammospheres: implications for vitamin D resistance in breast cancer and potential for Combination therapy. PLoS. 2013;8, e53287.

25. Singh R, Parveen M, Basgen JM, Fazel S, Meshesha MF, Thames EC, Moore B, Martinez L, Howard CB, Vergnes L, Reue K, Pervin S. Increased Expression of Beige/Brown Adipose Markers from Host and Breast Cancer Cells Influence Xenograft Formation in Mice. Mol Cancer Res. 2016;14(1):78-92.

26. Singh R, Avliyakulov KV, Braga M, Haykinson MJ, Martinez L, Singh V, Parveen M, Chaudhuri G, Pervin S. Proteomic identification of mitochondrial targets of arginase in human breast cancer. PLoS One. 2013;8, e79242.

27. Pervin S, Singh R, Chaudhuri G. Nitric oxide-induced cytostasis and cell cycle arrest of a human breast cancer cell line (MDA-MB-231): potential role of cyclin D1. Proc Natl Acad Sci USA. 2001;98:3583-8.

28. Thomas DD, Espey MG, Ridnour LA, Hofseth L, Mancardi D, Harris CC, Wink DA. Hypoxic inducible factor 1alpha, extracellular signal-regulated kinase, and p53 are regulated by distinct threshold concentrations of nitric oxide. Proc Natl Acad Sci USA. 2004;101:8894-9.

29. Namura S, Zhu J, Fink K, Endres M, Srinivasan A, Tomaselli KJ, Yuan J, Moskowitz MA. Activation and cleavage of caspase-3 in apoptosis induced by experimental cerebral ischemia. J Neurosci. 1998;18:3659-68.

30. Beyrich C, Löffler J, Kobsar A, Speer CP, Kneitz S, Eignethaler M. Infection of human coronary artery endothelial cells by group B streptococcus contributes to dysregulation of apoptosis, hemostasis, and innate immune responses. Mediators Inflamm. 2011;2011:971502.

31. Zhao B, He T. Chidamide, a histone deacetylase inhibitor, functions as a tumor inhibitor by modulating the ratio of $\mathrm{Bax} / \mathrm{BCl}-2$ and P21 in pancreatic cancer. Oncol Rep. 2015;33:304-10.

32. Gao G, Dou QP. N-terminal cleavage of bax by calpain generates a potent proapoptotic 18-kDa fragment that promotes bcl-2-independent cytochrome C release and apoptotic cell death. J Cell Biochem. 2000;80:53-72.

33. SUen DF, Norris KL, Youle RJ. Mitochondrial dynamics and apoptosis. Genes Dev. 2008:22:1577-90.

34. Wolff S, Erster S, Palacios G, Moll UM. p53's mitochondrial translocation and MOMP action is independent of Puma and Bax and severely disrupts mitochondrial membrane integrity. Cell Res. 2008;18:733-44.

35. Alavian KN, Beutner G, Lazrove E, Sacchetti S, Park HA, Licznerski P, Li H, Nabili P, Hockensmith K, Graham M, Porter Jr GA, Jonas EA. An uncoupling channel within the c-subunit ring of the F1FO ATP synthase is the mitochondrial permeability transition pore. Proc Natl Acad Sci USA. 2014;111:10580-5.

36. Becuwe P, Ennen M, Klotz R, Barbieux C, Grandemange S. Manganese superoxide dismutase in breast cancer: from molecular mechanisms of gene regulation to biological and clinical significance. Free Radic Biol Med. 2014;77:139-51.

37. Dontu G, Abdallah WM, Foley JM, Jackson KW, Clarke MF, Kawamura MJ, Wicha MS. In vitro propagation and transcriptional profiling of human mammary stem/progenitor cells. Genes Dev. 2003;17:1253-70.

38. Nandy SB, Ganwani L, Nahleh Z, Subramani R, Arumugam A, de la Rosa JM, Lakshmanaswamy R. Recurrence and metastasis of breast cancer is influenced by ovarian hormone's effect on breast cancer stem cells. Future Oncol. 2015;11:983-95.

39. DA Cruz PA, Marques O, Rosa AM, DE Fátima FM, Rêma A, Lopes C. Coexpression of stem cell markers ALDH1 and CD44 in non-malignant and neoplastic lesions of the breast. Anticancer Res. 2014;34:1427-34.

40. Schwartz T, Stark A, Pang J, Awuah B, Kleer CG, Quayson S, Kingman S, Aitpillah F, Abantanga F, Jiagge E, Oppong JK, Osei-Bonsu E, Martin I, Yan X, Toy K, Adjei E, Wicha M, Newman LA. Expression of aldehyde dehydrogenase 1 as a marker of mammary stem cells in benign and malignant breast lesions of Ghanaian women. Cancer. 2013;119:488-94.

41. Proctor E, Kidwell KM, Jiagge E, Bensenhaver J, Awuah B, Gyan K, Toy K, Oppong JK, Kyei I, Aitpillah F, Osei-Bonsu E, Adjei E, Ohene-Yeboah M, Brewer RN, Fondjo LA, Owusu-Afriyie O, Wicha M, Merajver S, Kleer C, Newman L. Characterizing Breast Cancer in a Population with Increased Prevalence of Triple-Negative Breast Cancer: Androgen Receptor and ALDH1 Expression in Ghanaian Women. Ann Surg Oncol. 2015;22:3831-5.

42. Glynn SA, Boersma BJ, Dorsey TH, Yi M, Yfantis HG, Ridnour LA, Martin DN, Switzer CH, Hudson RS, Wink DA, Lee DH, Stephens RM, Ambs S. Increased 
NOS2 predicts poor survival in estrogen receptor-negative breast cancer patients. J Clin Invest. 2010;120:3843-54.

43. Tudek B, Winczura A, Janik J, Siomek A, Foksinski M, Olinski R. Involvement of oxidatively damaged DNA and repair in cancer development and aging. Am J Transl Res. 2010;15:254-84.

44. Feairheller DL, Park JY, Sturgeon KM, Williamson ST, Diaz KM, Veerabhadrappa P, Brown MD. Racial Differences in oxidative stress and inflammation: in vitro and in vivo. Clin Transl sci. 2011;4:32-7.

45. Zhou L, Xiang W, Potts J, Floyd M, Sharan C, Yang H, Ross J, Nyanda AM, Guo Z. Reduction in extracellular superoxide dismutase activity in AfricanAmerican patients with hypertension. Free Radic Biol Med. 2006;41:1384-91.

46. Herway C, Kanninen T, Witkin SS, Saade G, Fortunato SJ, Menon R. Ethnic disparity in amniotic fluid levels of hyaluronan, histone $\mathrm{H} 2 \mathrm{~B}$ and superoxide dismutase in spontaneous preterm birth. J Perinat Med. 2013;41:277-82.

47. Millikan RC, Player J, de Cotret AR, Moorman P, Pittman G, Vannappagari V Tse CK, Keku T. Manganese superoxide dismutase Ala-9Val polymorphism and risk of breast cancer in a population-based case-control study of African Americans and whites. Breast Cancer Res. 2004;6:R264-74.

48. Shao J, Chen L, Marrs B, Lee L, Huang H, Manton KG, Martin GM, Oshima J. SOD2 polymorphisms: unmasking the effect of polymorphism on splicing. BMC Med Genet. 2007;8:7.

49. Grenados-Principal S, Liu Y, Guevara ML, Blanco E, Choi DS, Qian W, Patel T, Rodriguez AA, Cusimano J, Weiss HL, Zhao H, Landis MD, Dave B, Gross SS, Chang JC. Inhibition of iNOS as a novel effective targeted therapy against triple-negative breast cancer. Breast Cancer Res. 2015;17:25.

50. Rapozzi V, Della Pietra E, Zorzet S, Zacchigna M, Bonavida B, Xodo LE. Nitric oxide-mediated activity in anti-cancer photodynamic therapy. Nitric Oxide. 2013:30:26-35.

51. Kudo S, Nagasaki Y. A novel nitric oxide-based anticancer therapeutics by macrophage-targeted poly (l-arginine)-based nanoparticles. J Control Release. 2015;217:256-62.

52. Millet A, Bettaieb A, Renaud F, Prevotat L, Hammann A, Solary E, Mignotte B, Jeannin JF. Influence of the nitric oxide donor glyceryl trinitrate on apoptotic pathways in human colon cancer cells. Gastroenterology. 2002; 123:235-46.

53. Postovit LM, Adams MA, Lash GE, Heaton JP, Graham CH. Nitric oxidemediated regulation of hypoxia-induced B16F10 melanoma metastasis. Int J Cancer. 2004;108:47-53.

54. Frederiksen $\sqcup$, Sullivan R, Maxwell LR, Macdonald-Goodfellow SK, Adams MA Bennett BM, Siemens DR, Graham CH. Chemosensitization of cancer in vitro and in vivo by nitric oxide signaling. Clin Cancer Res. 2007;13:2199-206.

55. Simeone AM, Colella S, Krahe R, Johnson MM, Mora E, Tari AM. N-(4Hydroxyphenyl) retinamide and nitric oxide pro-drugs exhibit apoptotic and anti-invasive effects against bone metastatic breast cancer cells. Carcinogenesis. 2006;3:568-77.

\section{Submit your next manuscript to BioMed Central and we will help you at every step:}

- We accept pre-submission inquiries

- Our selector tool helps you to find the most relevant journal

- We provide round the clock customer support

- Convenient online submission

- Thorough peer review

- Inclusion in PubMed and all major indexing services

- Maximum visibility for your research

Submit your manuscript at www.biomedcentral.com/submit

) Biomed Central 